\title{
COMPARATIVE TECHNOLOGICAL AND COMMERCIAL EVALUATION OF FLAX VARIETIES FOR THE REVIVAL OF FLAX GROWING IN LATVIA
}

\author{
Silvija Kukle ${ }^{1}$, Veneranda Stramkale ${ }^{2}$, Dace Kalniṇa ${ }^{1}$, \\ Dagmāra Prīberga ${ }^{1}$, Guntis Strazds ${ }^{3}$ \\ 1- Riga Technical University, Department of Design and Textile Products Technology \\ Azenes St14/24, Riga, LV 1048, Latvia \\ Ph.: +(371 ) 67089816, fax: +(371) 67089816, e-mail: sv85@inbox.lv \\ 2- Agriculture Science Centre of Latgale \\ Kulturas sq. 1a, Vilani, Rezeknes distr., LV 4650 \\ Ph.: +371 64628140, +371 29465004, e-pasts: strzin@apollo.lv \\ 3- Association of Textile and Clothing Industry \\ Ph.: +37129488338
}

\begin{abstract}
As renewable raw material flax increasingly gain more importance as the range of its use is spreading more and more. Besides the conventional uses in home textiles, clothing and sails products, demand of flax raw materials for technical uses increases rapidly as flax fibers have high specific properties, become components of biodegradable composites, environmental friendly isolation materials, besides flax shives pay attention as well as components of environment friendly building materials. Unfortunately in Latvia during last decades flax crop production had decreased rapidly and nowadays reintroduction of flax growing traditions and conditions are become more and more actual. In spite of depression in sector, in Agriculture Science Centre of Latgale are not interrupted experiments on development of local flax lines. Field trials were sown at the Centre in 2010 and 98 flax lines investigated. In this article reflected analysis results of one perspective local fibers flax line from different aspects and its properties comparison with the standard fibers flax variety Vega 2.
\end{abstract}

Keywords: flax, fibers, variety, bast crop production, biodegradable, renewable recourses.

\section{Introduction}

In conformity with the world trend a more intensive use of renewable raw materials gets more and more attention from police makers and scientists. Bast crop production is one of opportunity to supply renewable raw materials for a wide range of applications. In the same time it is an important key to the creation of employment in crop growing and processing areas and the development of a sustainable economy of the region and country.

As renewable raw material flax increasingly gain more importance as the range of its use is spreading rapidly. Besides the conventional uses in home textiles, clothing and sails products, demand of flax raw materials increases for technical uses as flax fibers have high specific properties: a low density, water absorption, they are soft and flexible, stronger than cotton or wool. Moreover, all flax components are recyclable and fully combustible without the production of noxious gases, can be obtained at a comparatively low cost. Strength and biodegradability attract attention as reinforcement of partly or fully biodegradable fiber plastic composites and breathing isolation materials. Even the woody core shives, which are removed during scutching, are used for particleboards and animal bedding (9)

As flax is a crop for temperate regions and requires abundant moisture and cool weather during the growing season (Berger, 1969) it meets proper Latvian climate conditions. Although climate conditions is favourable for flax cultivation, during last decades flax crop production in country was decreased fast (Developm., 2006). At the same time flax is one of the oldest sources of textile fibers used all around in the world as well in Latvia too. At the 
first part of twenty century Latvia was successful in flax fibers export to European countries. Nowadays flax fibers is a scarce resource in Latvia, our linen producers are almost fully dependent from imports (Fig. 1).

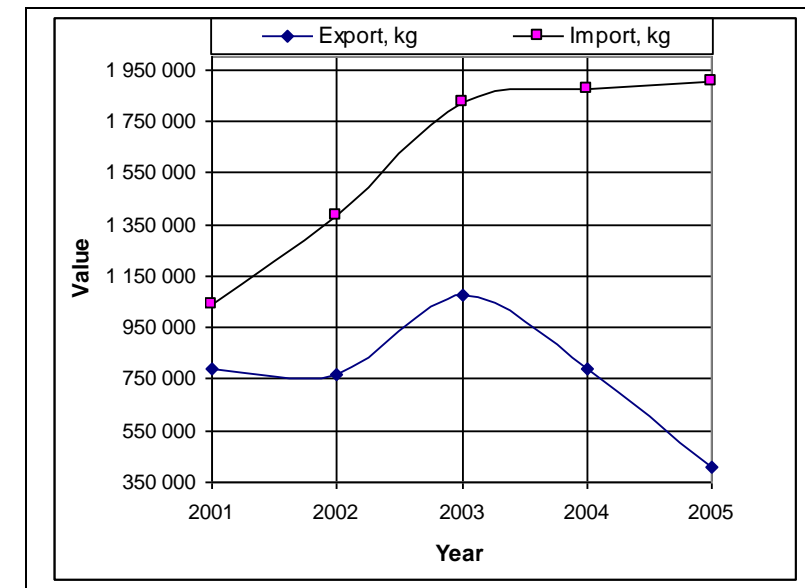

Fig. 1. Latvian flax fibers export-import balance ${ }^{2}$

\section{Materials, methods}

The reintroduction of a crop involves the question of quality and predictability, as well as the environmental conditions under which profitable production may be undertaken. Varieties enter into the quality and predictability of the crop. The object of our work has been to determine which variety is most desirable from the standpoint of fiber production and determine predictability of agronomical, commercial and technological properties. In order to solve this problem, a comparative study of properties of available local 98 flax varieties/lines cultivated in field experiments in Agriculture Science Centre of Latgale at 2010 was made, following the routine methods (Stramk., 2009) and compared with the corresponding properties of Lithuanian variety Vega 2 as a standard. Summer of year 2010 with high temperatures and unsufficient rains was quite unfavorable for flax growing. Varieties were evaluated and compared for 8 commercial and fibers production variables (Stramk, 2010), a description of variations in the performance of fiber flax varieties is also necessary as current guidance and the differences between the varieties were analysed. As for varieties and lines under inspection variability of properties are high, analysis is carried out by using methods of mathematic statistics such as descriptive statistics, correlation, distribution curves and regression analysis.

To investigate interdependence between variables with influence on fibres productivity correlation coefficients $\mathrm{R}$ are calculated for variables average values of all 98 varieties (Table 1). Largest values of correlation coefficient take place between unretted stem yield and bast and shives yield, respectively $\mathrm{R}=0,78$ and 0,73 , corresponding determination coefficients 61 $\%$ and $53 \%$; more impact on retted stem yield has shives yield $(\mathrm{R}=0,83)$, less fibres yield $\mathrm{R}=0,7$. Coefficients with values in range from 0,7 till 0,5 witness on medium strong correlation between unretted and retted stem yield $(0,61)$, bast and fibres content $(0,66)$, retted shives and fibres densities $(0,65)$; values close to 0,2 or less present evidence that no correlation between corresponding variables at all. It means that after retting correlation absent between fibres yield and fibres content, stem yield and fibres content.

As it is not easy in flax growing practice to make decisions with a line of variables, all range of varieties/lines were sorted by fibers content and by fibers yield, as a result first 12 varieties with the best values of main parameter are separated (fig.2 and 3). 
Correlation matrix

Table 1.

\begin{tabular}{|c|c|c|c|c|c|c|c|c|}
\hline & \multicolumn{4}{|c|}{ Unreted } & \multicolumn{4}{|c|}{ Dew reted } \\
\hline & $\begin{array}{l}\text { Stem } \\
\text { yield, } \\
\mathrm{g} / \mathrm{m}^{2}\end{array}$ & $\begin{array}{l}\text { Bast } \\
\text { content, } \\
\%\end{array}$ & $\begin{array}{l}\text { Bast } \\
\text { yield, } \\
\mathrm{g} / \mathrm{m}^{2}\end{array}$ & $\begin{array}{l}\text { Shives } \\
\text { yield, } \\
\text { g/m2 }\end{array}$ & $\begin{array}{l}\text { Stem } \\
\text { yield, } \\
\mathrm{g} / \mathrm{m}^{2}\end{array}$ & $\begin{array}{l}\text { Fibers } \\
\text { content, } \\
\%\end{array}$ & $\begin{array}{l}\text { Fibers } \\
\text { yield, } \\
\text { g/m² }\end{array}$ & $\begin{array}{l}\text { Shives } \\
\text { yield, } \\
\mathrm{g} / \mathrm{m}^{2}\end{array}$ \\
\hline $\begin{array}{l}\text { Stem yield, } \\
\mathrm{g} / \mathrm{m}^{2}\end{array}$ & 1,00 & & & & & & & \\
\hline $\begin{array}{l}\text { Bast } \\
\text { content, \% }\end{array}$ & 0,29 & 1,00 & & & & & & \\
\hline $\begin{array}{l}\text { Bast yield, } \\
\mathrm{g} / \mathrm{m}^{2}\end{array}$ & 0,78 & 0,38 & 1,00 & & & & & \\
\hline $\begin{array}{l}\begin{array}{l}\text { Shives } \\
\text { yield, } \mathrm{g} / \mathrm{m} 2\end{array} \\
\end{array}$ & 0,73 & 0,23 & 0,72 & 1,00 & & & & \\
\hline $\begin{array}{l}\text { Stem yield, } \\
\mathrm{g} / \mathrm{m}^{2}\end{array}$ & 0,61 & 0,31 & 0,70 & 0,58 & 1,00 & & & \\
\hline $\begin{array}{l}\text { Fibers } \\
\text { content, \% }\end{array}$ & 0,21 & 0,66 & 0,28 & 0,10 & 0,16 & 1,00 & & \\
\hline $\begin{array}{l}\text { Fibers } \\
\text { yield, } g / \mathbf{m}^{2} \\
\end{array}$ & 0,56 & 0,33 & 0,61 & 0,41 & 0,70 & 0,29 & 1,00 & \\
\hline $\begin{array}{l}\text { Shives } \\
\text { yield, } g / \mathrm{m}^{2}\end{array}$ & 0,58 & 0,18 & 0,57 & 0,52 & 0,83 & 0,09 & 0,65 & 1,00 \\
\hline
\end{tabular}

As seen from Fig. 2 graph for all 12 selected varieties/lines fibres contents are higher then for standard variety Vega 2 (for line S37-11/15-93 diference $22 \%$ ). The graph testify that inside this short range correlation between bast content and fibers content after dew retting absent too.

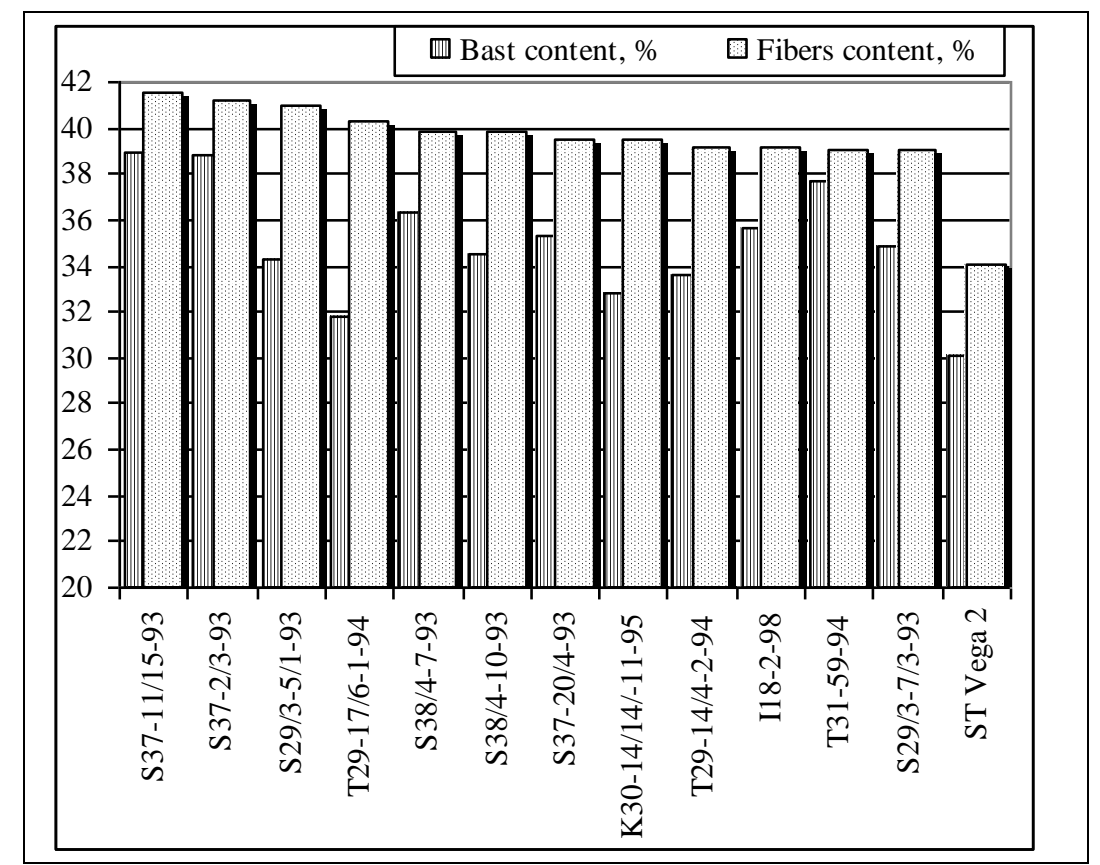

Fig. 2. Alteration of fiber contents after dew retting

Sorting results by fiber yield values shown in Fig.3 represent first twelve favourable by this property flax lines. Diference between line with higher rank and standard variety is quite 
impressive $-43,6 \%$. It is not hard to see from Table 2 that varieties/lines in both columns are different. As a cosequence question arise which of these two properties are more important? More commercial is second one - customers pay for fibers yield.

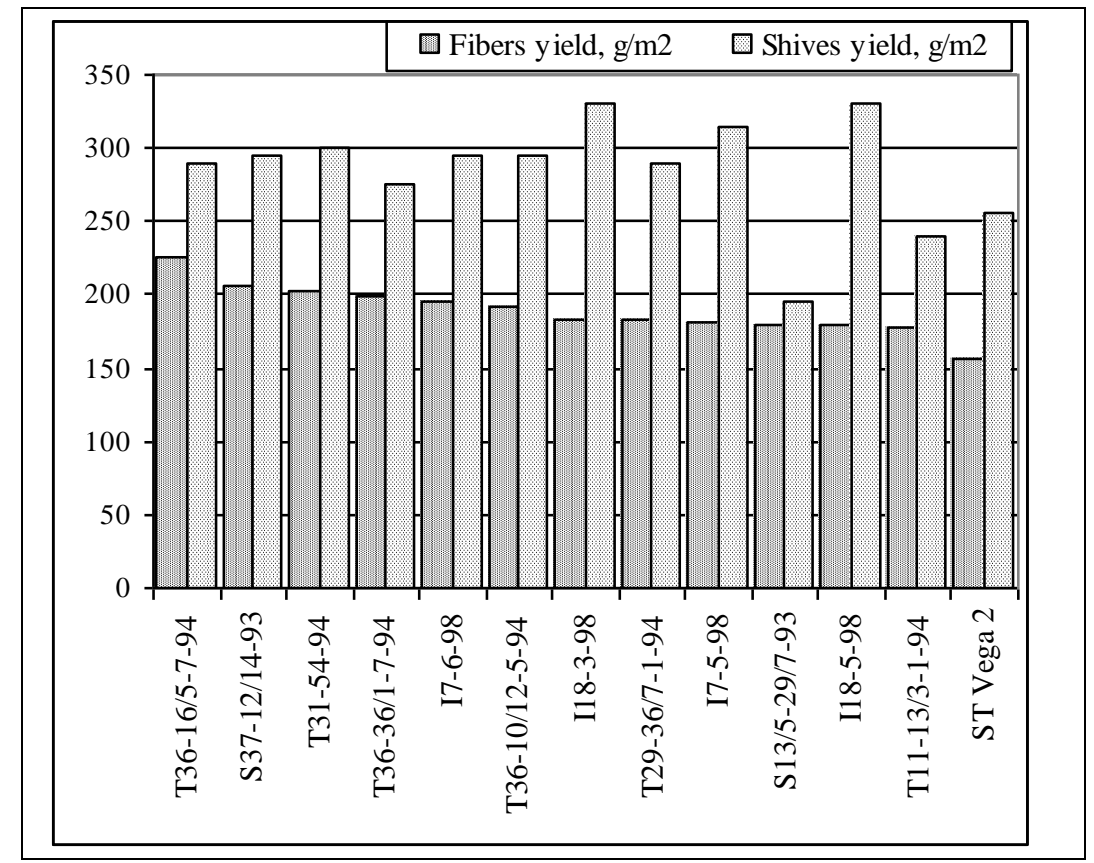

Fig. 3. Alteration of flax fiber yield after dew retting

\section{Comparative range of flax lines sorted by fibers content and fibers density after dew retting}

\begin{tabular}{|l|l|l|}
\hline & \multicolumn{2}{|c|}{ Flax variety/line } \\
\hline & $\begin{array}{l}\text { Sorted by fibers } \\
\text { content }\end{array}$ & $\begin{array}{l}\text { Sorted by fibers } \\
\text { yield }\end{array}$ \\
\hline 1 & $\mathrm{~S} 37-11 / 15-93$ & $\mathrm{~T} 36-16 / 5-7-94$ \\
\hline 2 & $\mathrm{~S} 37-2 / 3-93$ & $\mathrm{~S} 37-12 / 14-93$ \\
\hline 3 & $\mathrm{~S} 29 / 3-5 / 1-93$ & $\mathrm{~T} 31-54-94$ \\
\hline 4 & $\mathrm{~T} 29-17 / 6-1-94$ & $\mathrm{~T} 36-36 / 1-7-94$ \\
\hline 5 & $\mathrm{~S} 38 / 4-7-93$ & $\mathrm{I} 7-6-98$ \\
\hline 6 & $\mathrm{~S} 38 / 4-10-93$ & $\mathrm{~T} 36-10 / 12-5-94$ \\
\hline 7 & $\mathrm{~S} 37-20 / 4-93$ & $\mathrm{I} 18-3-98$ \\
\hline 8 & $\mathrm{~K} 30-14 / 14 /-11-95$ & $\mathrm{~T} 29-36 / 7-1-94$ \\
\hline 9 & $\mathrm{~T} 29-14 / 4-2-94$ & $\mathrm{I} 7-5-98$ \\
\hline 10 & $\mathrm{I} 18-2-98$ & $\mathrm{~S} 13 / 5-29 / 7-93$ \\
\hline 11 & $\mathrm{~T} 31-59-94$ & $\mathrm{I} 18-5-98$ \\
\hline 12 & $\mathrm{~S} 29 / 3-7 / 3-93$ & $\mathrm{~T} 11-13 / 3-1-94$ \\
\hline
\end{tabular}

From a technological viewpoint fiber yield is more important too, but not less important are technological properties which are differ dependent on technology applied for processing and end usage of fibres. Important for most applications are fibres tensile properties. In this article is compared tensile strength of a small fiber bundles prepared for testing with $3 \mathrm{~mm}$ distance between clamps, testing clamp velocity $150 \mathrm{~mm} / \mathrm{min}$. of local variety T36-16/5-7-94 and standard Vega 2. In the result of tensile tests of one hundred samples from line T36-16/5- 
7-94 and standard variety Vega 2 is found out that average tensile strenght of T36-16/5-7-94 is almost 2 times higher than for Vega 2 fibers (Table 3).

Table 3.

Comparative tensile strength parameters of flax line T36-16/5-7-94 and variety Vega 2

\begin{tabular}{|c|c|c|c|c|c|}
\hline & $\begin{array}{c}\text { Average, } \\
\mathbf{N}\end{array}$ & $\begin{array}{c}\text { Mode, } \\
\mathbf{N}\end{array}$ & $\begin{array}{c}\text { Median, } \\
\mathbf{N}\end{array}$ & $\begin{array}{c}\text { Range, } \\
\mathbf{N}\end{array}$ & $\begin{array}{c}\text { Absolute } \\
\text { deviation, } \mathbf{N}\end{array}$ \\
\hline Vega 2 & 10,35 & 10,30 & 10,30 & 16,7 & 0,37 \\
\hline T36-16/5-7-94 & 20,40 & 18,00 & 19,25 & 17,2 & 0,42 \\
\hline Diference, \% & $97 \%$ & $75 \%$ & $87 \%$ & $3 \%$ & $15 \%$ \\
\hline
\end{tabular}

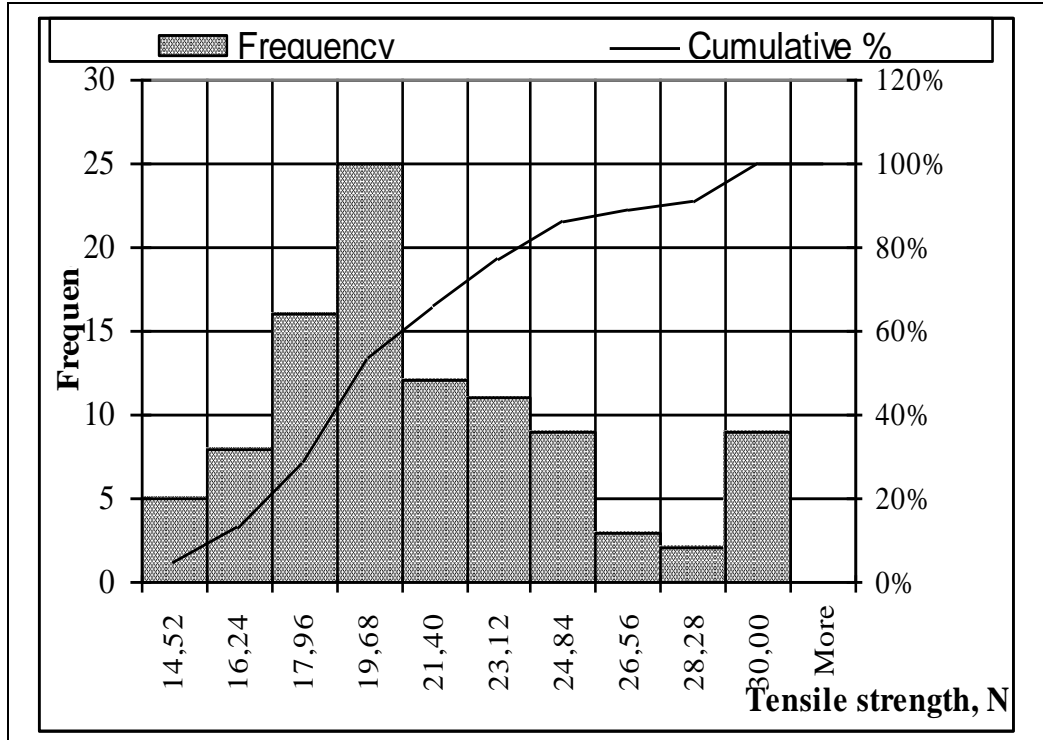

Fig. 4. Tensile strength histogram of flax line T36-16/5-7-94

\section{Results and discussion}

As seen from tables 2 and 3 identified flax line T36-16/5-7-94 developed in Agriculture Science Centre of Latgale shows higher fiber yield in 2010 as standard variety Vega 2 (43,6 $\%$ ) and quite high fibres content - 37,7 \%. From commercial viewpoint line T36-16/5-7-94 is quite promising breeding line for further developments to create flax variety resistant to dry and warm weather conditions during vegetation period.

Agriculturally important traits, such as flax total plant height $90 \mathrm{~cm}$, technical plant height $78,2 \mathrm{~cm}$ (higher then for the selected best lines in period 2007-2008, Grauda, 2009 and TOND., 2003), logging resistance 9, vegetation period 75 days, yield of straws $6130 \mathrm{~kg} / \mathrm{ha}$ and yield of seeds $670 \mathrm{~kg} / \mathrm{ha}$ (Stramk., 2010) are reasonable. Comparison of properties of the line T36-16/5-7-94 with properties of the line S37-11/15-93 shows that flax average total plant height $84,4 \mathrm{~cm}$ and technical plant height $73,8 \mathrm{~cm}$ are lower, logging resistance 10 higher, vegetation period 81 days longer, yield of straws $5430 \mathrm{~kg} / \mathrm{ha}$ lower, and yield of seeds $1160 \mathrm{~kg} / \mathrm{ha}$ (Stramk, 2010) higher then corresponding agricultural properties of the line T3616/5-7-94. Retted fibres yield is 1,38 times higher for the flax line T36-16/5-7-94 to compare with S37-11/15-93. 


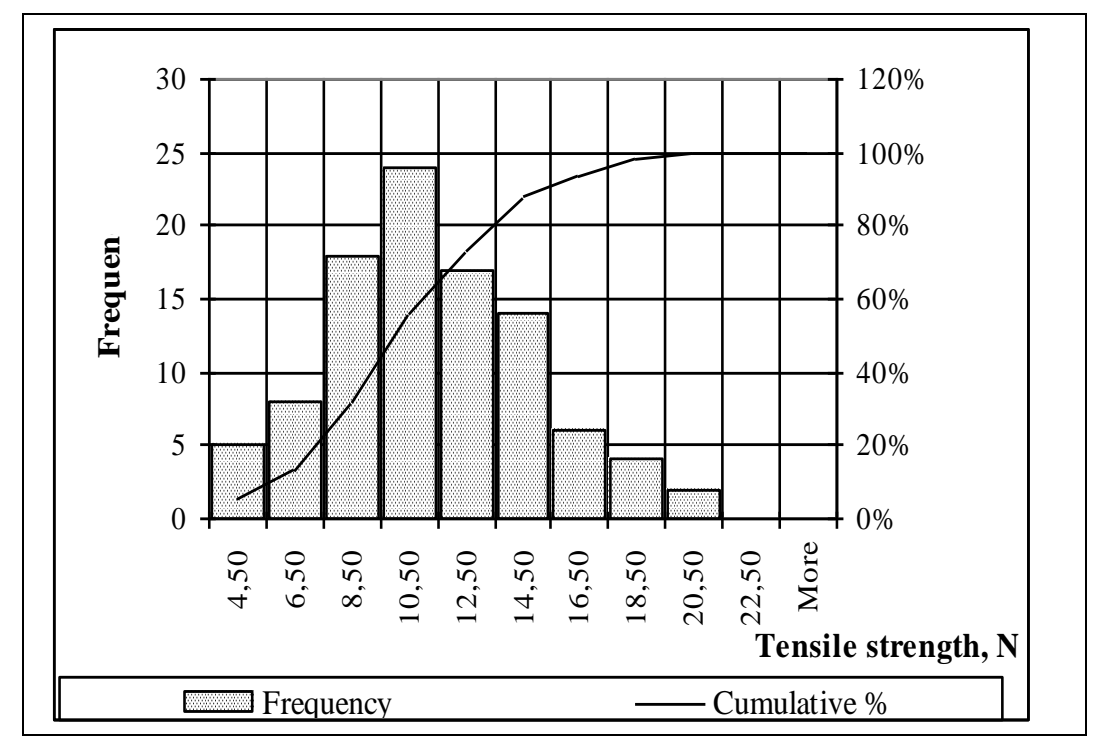

Fig. 5. Tensile strength histogram of flax standard variety Vega 2

To evaluate this variety from technological and usage viewpoints from Table 3 and compare graphs of Fig. 4 and Fig. 5 we can see that flax line's T36-16/5-7-94 all main parameters of tensile strength distribution are higher then for Vega 2 (Table 3). Distribution in entirety of T36-16/5-7-94 is shifted to higher tensile strength values compare with histogram of Vega 2 (Fig. 3 and Fig. 4) and is missing quite voluminous ( $30 \%)$ segment of fibres with tensile strength 6,5 $\mathrm{N}$ and less. Inspected characteristics are important for flax fibres processed into consumer or technical textiles or composite materials.

\section{Conclusions}

Flax breeding line T36-16/5-7-94 shows higher agricultural, commercial and technological properties resisting to unfavourable for the flax cultivation climate conditions at summer of year 2010 and in that way is treated as a serious candidate for the development of local fibres flax variety with medium long vegetation period, resistant to extreme weather conditions and with good commercial and technical performance.

\section{References}

1. Berger, J., 1969. In: The World's Major Fibre Crops their Cultivation and Maturing. Part 1. Flax. pp. 209213.V.

2. Development of Experimental Flax Processing Manufacture. Technical and Economical Motivation, developed by Latvian Association of Textile and Clothing Industry \& Ltd. Inventio, 2006.

3. van TONDER C.S.M, JANSEN A., JACOBS M.\& van der MERWE D W. Adaptability of European fibre and linseed flax cultivars to South African conditions. In: African Crop Science Conference Proceedings, Vol. 6., 2003, p. 38-41, ISSN 1023-070

4. V.Stramkale, A.Stramkalis, L.Komlajeva, M.Selecka, M.Vikmane, A.Stalats. Evaluation of Latvian Flax Varieties by Seed Yield and Quality. In: Book of proceedings of the 7th International Scientific and Practical Conference, Technology. Resources, Volume 1, 2009, pp. 135-140. ISSN 1691-5402; ISBN 9789984-44-027-9

5. V.Stramkale. Latvijas atjaunojamo izejvielu - linu un kaņepāju produktu īpašǐbu pētījumi, to pielietošana inovatīvu tehnologiju un jaunu funkcionālu materiālu izstrādei. Pārskats par 2010. gadu. SIA” Latgales lauksaimniecības zinātnes centrs", 1. un 2. daļa, Vilani.

6. Grauda D., Stramkale V., Komlajeva L., Kolodinska Bratestam A., Mik̦elsone A., Lapiña L., Auziņa A. and Rashal I. Evaluation of the Latvian Flax Genetic Resources and Perspective of their Utilisation. In: Book of proceedings of the 7th International Scientific and Practical Conference, Technology. Resources, Volume 1, 2009, pp. 160-165. ISSN 1691-5402; ISBN 978-9984-44-027-9 